\title{
POPULATION DYNAMICS OF EUXESTA SPP. (DIPTERA: OTITIDAE) IN MAIZE (Zea mays L.), WHEAT (Triticum aestivum L.) AND POLYCULTURE
}

\author{
MARIANA BONIFÁCIO AMANCIO ${ }^{1}$ and IVAN CRUZ ${ }^{2}$
}

${ }^{1}$ Universidade Federal de Minas Gerais, Belo Horizonte-MG Brasil, bonifacioamancio@hotmail.com

${ }^{2}$ Embrapa Milho e Sorgo, Sete Lagoas-MG Brasil, Rod MG 424 Km 45, Zona Rural, 35701-970.Brazil,ivan.cruz@embrapa.br

$\overline{\text { Revista Brasileira de Milho e Sorgo, v.18, n.3, p. 311-321, } 2019}$

\begin{abstract}
In Brazil there is a great concern about the incidence of insect pests on reproductive organs of plants. In maize, there has been some species of Euxesta (Diptera: Otitidae) flies causing damage, especially in sweet maize. The objective of this study was to evaluate the presence of Euxesta spp. in maize, wheat and polyculture. For this, two experiments were carried out in a savanna area. The first was set in two potential hosts, the high protein white maize and the wheat, the second experiment was carried out in a polyculture system (maize, soybean, sorghum and cotton). The insects were captured weekly until the end of cultivation through McPhail traps with hydrolyzed maize protein randomly distributed in both fields..Two species, Euxesta eluta and Euxesta mazorca, were sampled. There was a greater collection of individuals in maize compared to wheat. Higher number of E. eluta was observed in soybean and cotton, followed by maize 1 and 2 and sorghum. The number of E. maize was found to be higher in the two kinds of maize, soybean, cotton and sorghum. The number of females was higher than males in both crops.
\end{abstract}

Keywords: Monitoring, spike fly, Euxesta eluta, Euxesta mazorca, attractive food.

\section{FLUTUAÇÃO POPULACIONAL DE EUXESTA SPP. (DIPTERA: ULIDIIDAE) NA CULTURA DO MILHO (Zea mays L.), TRIGO (Triticum estivum L.) E POLICULTIVO}

RESUMO - No Brasil, há grande preocupação com a incidência de insetos-pragas em órgãos reprodutivos das plantas. No milho, houve uma espécie significativa da mosca Euxesta (Diptera: Otitidae) causando danos especialmente em milho-doce. O objetivo deste trabalho foi avaliar a presença de Euxesta no milho, trigo e policultivo. Para isso foram realizados dois experimentos semeados em área de cerrado. O primeiro, em dois potenciais hospedeiros, o milhobranco de alta qualidade proteica e o trigo; o segundo experimento foi realizado em sistema de policultivo (milho, soja, sorgo e algodão). Através de armadilhas McPhail com proteína hidrolisada de milho, distribuídas aleatoriamente em ambos os campos, avaliou-se a captura dos insetos semanalmente, até o final do cultivo. Duas espécies, Euxesta eluta e Euxesta mazorca, foram amostradas. Houve uma maior coleta de indivíduos no milho em relação ao trigo. Maiores números de E. eluta foram observados na soja e no algodão, seguidos pelo milho 1 e 2 e sorgo. O E. eluta foi considerado mais alto em dois tipos de milho, soja, algodão e sorgo. O número de fêmeas foi superior ao dos machos nas duas culturas.

Palavras-chave: Monitoramento, mosca-da-espiga, Euxesta eluta, Euxesta mazorca, atrativo alimentar. 
In Brazil there is a great concern about the incidence of insect pests on reproductive organs of plants. Such reproductive structures include maize ears (Zea mays L.), wheat panicles (Triticum aestivum L.), soybeans (Glycine max L.) or bean pods (Phaseolus vulgaris L.). In addition to the direct injury to the final consumer of the product, such attack sites usually protect the pest from the action of conventional control measures, as is the case of chemical spraying, and do not avoid the risk of contamination, especially considering the short period between applications and harvest (Cruz et al., 2011a). This is the case of the Heliothinae group, whose latest representative in Brazil is Helicoverpa armigera (Hübner) (Lepidoptera: Noctuidae), the complex Spodoptera (Lepidoptera: Noctuidae) and the ear fly Euxesta spp. (Diptera: Ulidiidae).

Susceptibility of commercial cultivars and the risk of contamination of grains when using spraying with chemicals to control pests are limiting factors in avoiding insect injury. In sweet and high-quality protein white maize intended primarily for direct human consumption "in natura" or canned (sweet), or as bread and biscuit (flour), the risk of contamination by the chemicals used directly into the ear is very high. Bt maize cultivars have not yet been used. Commercial absence of Bt cultivars, natural rejection by the consumer and inefficiency in the fly control have been the constraint points to sweet/white maize cultivation in Brazil. Unfortunately, basic information including existing species, hosts and fluctuation over the time is still lacking (Cruz et al., 2011b). Cruz et al. (2011b) reported the presence of the insect in agricultural areas even when the plant is not on the preferred stage to feed the larvae.

Usually in groups, Euxesta larvae attack maize kernels located at the tip of the ear, resulting in a putrefaction process and favoring the attack of birds and other insects. According to Link et al. (1984), Euxesta larvae has the ability to magnify the damage already caused in maize by Helicoverpa zea (Bodie) (Lepidoptera: Noctuidae) and in this case the hole ear will be unusable. Villas Boas and França (1989) reported that this pest also occurs in the ear, regardless the presence of other insects at the same location.

Larvae of Euxesta spp. attack tips of maize cob, especially sweet maize, causing rotting of grains. The larvae initially feed on the stigma-style and subsequently the developing grain, making maize cob improper for consumption (Gallo et al., 2002; Cruz, 2008; Nuessly \& Capineira, 2006; Cruz et al., 2011b). The adult presents five millimeters long with dark coloration; their wings are colorless but showing dark spots. The oviposition is made on the stigma-style and the larvae hatching occurs two to three days after laying (Cruz, 2008; Cruz et al., 2011b).

Although considered a minor pest in conventional maize (Branco et al., 1994; Cruz et al., 2011b), its economic importance is too great for sweet maize or varieties with softer grains (Cruz, 2008; Cruz et al., 2011b). The Euxesta spp. larvae penetrate the grain, where they complete their immature development. Often the larvae penetrate the seed embryo, feeding entirely on the grain, leaving only the outer membrane (Cruz, 2008; Cruz et al., 2011b). According to Cruz et al. (2011b), Euxesta eluta Loew and E. mazorca Steyskal were the only species captured in McPhail trap in Brazil.

The objective of this study was to evaluate the presence of ear fly Euxesta spp. in wheat and in high protein quality white maize (QPM maize). 


\section{Material and methods}

Two experiments were performed in a savanna region, in Sete Lagoas, Minas Gerais, Brazil (19 ${ }^{\circ} 28$ ' 00 ' ' $\mathrm{S}$ and $44^{\circ} 15^{\prime} 00$ ' $\left.\mathrm{W}\right)$, in the experimental fields of the Brazilian Agricultural Research Institution (Embrapa).The first experiment was a polyculture and occurred from January to June 2015. The polyculture was composed of two varieties of maize, soybean, sorghum and cotton (cultivars Brs ViVi, Dv B390 VtPro, 3858180 RR, DP 1228B 2RF, BRS655, respectively). The maize density was five seeds $/ \mathrm{m}$, spaced $0.70 \mathrm{~cm}$, while the soybean density was 6 seeds $/ \mathrm{m}$ spaced $0.30 \mathrm{~cm}$, and for sorghum 20 seeds were spaced $0.60 \mathrm{~m}$. For cotton cultivation, ten seeds $/ \mathrm{m}$ were sown at a diameter of $0.70 \mathrm{~cm}$. The whole area received fertilization of 300 $\mathrm{kg}$ ha-08-28-16 NPK + Zn.

The second experiment occurred from August to November of the same year and comprised two areas; the first area of 5.5 ha was cultivated with white maize (cultivar BR 451) and the second with wheat (cultivar BRS 264). Maize density was 5 seeds $/ \mathrm{m}$, spaced $0.70 \mathrm{~cm}$ and fertilized with $500 \mathrm{~kg}$ ha-1 of 28/08/16 NPK + Zn. The density of wheat seeds was 80 seeds $/ \mathrm{m}$ in a 2.5 ha area, spaced $0.22 \mathrm{~m}$ and fertilization used $300 \mathrm{~kg}$ ha-08-28-16 NPK + Zn.

In both experiments, to attract Euxesta spp. the BioAnastrepha ${ }^{\circledR}$ food bait (hydrolyzed maize protein) with a concentration of 5\% (300 ml solution / trap) was placed inside the McPhail trap (Steyskal, 1965). This protein source is registered in Brazil to attract the true fruit fly specifically in association with the McPhail trap. The distance between the traps was 50 meters (eight in each cultivation area), installed one meter above the ground surface. When the plants reached trap height, they increased dynamically to always remain in the plant canopy. Monitoring in each growing area began 30 days after seed germination.

Assessments started four days after the trap field was set and were accomplished twice a week. After each evaluation period, the traps received a new food source. In addition, trap reorganization was performed in each field, always following a random block pattern. After each evaluation, using a fine mesh screen, the insects removed from the traps were sorted and stored in glass bottles containing 70\% alcohol, according to species and genus.

The identification of E. eluta and E. mazorca was based on the morphological differences already described, such as the color and pattern of distribution of wing stains, head structure and oviduct. The differentiation between the two species was easily accomplished by the macroscopic characteristics presented on their wings, indicating well defined black tones at the beginning and end of the wings in $E$. mazorca. In addition, the body shape is slightly larger than E. eluta's body (Steyskal, 1968; Huepe et al., 1986). Sex ratio (RS) was calculated using the formula:

$R S=$ number of females/ (number of females + number of males

Meteorological data, average temperature, average humidity, precipitation, solar radiation and evaporation were monitored in both trials. Data were collected at the Conventional Weather Station of Sete Lagoas - Inmet, deactivated in 2016: 732m altitude, $19^{\circ} 28^{\prime} 00$ 'S latitude, $44^{\circ} 15^{\prime} 00^{\prime \prime} \mathrm{O}$ longitude. At the end of the evaluations, the vials containing the specimens were deposited at the Embrapa Maize and Sorghum Entomological Museum in Sete Lagoas, Minas Gerais, Brazil. The number of individuals collected was submitted to analysis of variance with means compared by Tukey test at $5 \%$ probability by the SISVAR program (Ferreira, 2011). 


\section{Results and discussion}

In the experiments, the presence of Euxesta eluta Loew, 1868 (Diptera: Otitidae) and E. mazorca Steyskal (Diptera: Otitidae) was recorded.

During the experiment carried out in polyculture, the mean number of Euxesta insects captured during the entire experimental period was 19,830, being 9,618 E. mazorca and 10,212 E. eluta. In the treatments with cotton and soybean, the number of $E$. eluta was statistically higher than $E$. mazorca, with 3,241 and 3,391 E. eluta and 1,647 and 1,706 E. mazorca captured, respectively. In the sorghum, maize 1 and maize 2 treatments, the number of E. eluta was lower than the number of E. mazorca caught $(630,1,575$ and 1,375 E. eluta for 1,300, 3,167 and 1,798 E. mazorca, respectively) (Table 1).

In all treatments, for both species, the sex ratio was close to or greater than 0.80 for E. eluta, whereas E. mazorca presented values below 0.80 in soybean and sorghum crops ( 0.79 and 0.76 , respectively), but E. eluta showed results equal to or greater than 0.80 in all crops, as shown in Table 1.

Both species of Euxesta showed well-defined population peaks during the first three evaluation periods. It was observed that the largest collection of individuals of E. eluta species at the beginning of the evaluations occurred in cotton and soybean crops, while the other treatments presented low variations and constant population throughout the experimental period (Figure 1). These values were also statistically similar for the total analysis of insects captured in the experimental areas (Table 1).

As previously mentioned, E. mazorca showed a population peak in sorghum crop on the second day of evaluation, with a subsequent high decrease. This population peak recurred, although with less intensity, during the mid-phase of the experiment (Figure 2). The other treatments showed similar behavior until the end of the trial. Only in the area destined for maize 1 there was a slight delay in the population peak in the first days of evaluation compared to the treatments comprising maize 2, sorghum, wheat and cotton (Figure 2). These two treatments presented higher levels compared to the others during the middle and final stages of evaluation; in both periods, sorghum was slightly more attractive than corn 2 for E. mazorca. The other treatments were constant until the end of the evaluation periods. Despite the population peaks, maize 1 was statistically more attractive to E. mazorca than the other treatments (Table 1). The meteorological data during the polyculture experiment are shown in Figure 3.

Population peaks occurring in different crops at different times can be explained by the phenological characteristics of each treatment. Cotton crops are commonly attacked by several phytophagous pests at the early developmental stages, including thrips (Thrips tabaci and Frankliniella sp.), Aphids (Aphis gossypii and Myzus persicae) and whitefly (Bemisia tabaci and B. argentifolli) (Miranda, 2008). Similarly, soybean is affected by several pests shortly after germination, including soybean weevil (Sternechus subsignatus), the elasmo caterpillar (Elasmopalpus lignosellus), the chorus (Scarabaeoidea) and the root brown stink bug (Scaptocoris castanea and Atarsocoris brachiariae) which damage the crop.

The emergence of Euxesta is generally associated with other pests, since leaf exudates that arise after the attack of other insects have been used as a food source, in addition to the high polyphagia of the species under study (Capineira, 2000; Gould et al., 2002; Goyal 2010). According to Goyal (2010), weeds also serve as an alternative pest environment, 
Table 1. Number of adults caught and sex ratio of Euxesta eluta and Euxesta mazorca in polyculture in the experimental fields of Embrapa in Sete Lagoas, MG.

\begin{tabular}{ccccc}
\hline & Average number of captured insects & Sexual ratio \\
\hline Treatments/Crops & Euxesta eluta & Euxesta mazorca & Euxesta eluta & Euxesta mazorca \\
\hline Corn (Brs ViVi) & $131.25 \mathrm{Ab}$ & $263.91 \mathrm{Bb}$ & $0.80 \mathrm{Aa}$ & $0.82 \mathrm{Aa}$ \\
\hline Corn 2 (Dv B390 VtPro) & $114.58 \mathrm{Aa}$ & $149.83 \mathrm{Ab}$ & $0.83 \mathrm{Aa}$ & $0.83 \mathrm{Aa}$ \\
\hline Soybean & $282.58 \mathrm{Ba}$ & $142.16 \mathrm{Ab}$ & $0.80 \mathrm{Aa}$ & $0.79 \mathrm{Aa}$ \\
\hline Sorghum & $52.50 \mathrm{Aa}$ & $108.33 \mathrm{Aa}$ & $0.84 \mathrm{Aa}$ & $0.76 \mathrm{Aa}$ \\
\hline Cotton & $270.08 \mathrm{Bb}$ & $137.25 \mathrm{Ab}$ & $0.80 \mathrm{Aa}$ & $0.83 \mathrm{Aa}$ \\
\hline CV (\%) & 33.99 & 25.95 & 9.3 & 9.59 \\
\hline F & 2.32
\end{tabular}

Means followed by the same capital letter in the column do not differ from each other by Tukey's test at the 5\% probability level.

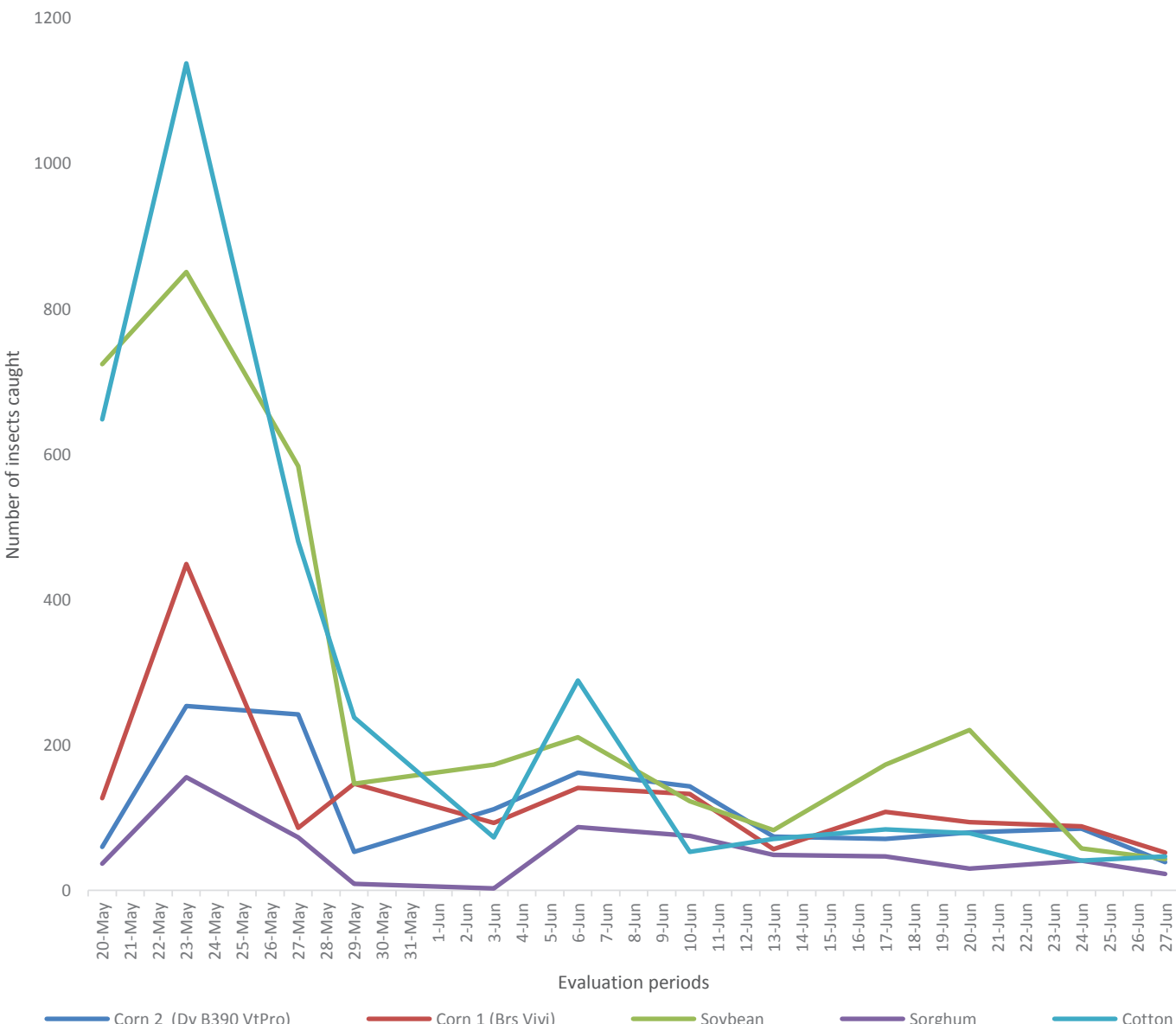

Figure 1. Euxesta eluta population peaks during polyculture in the experimental fields of Embrapa in Sete Lagoas, MG. 


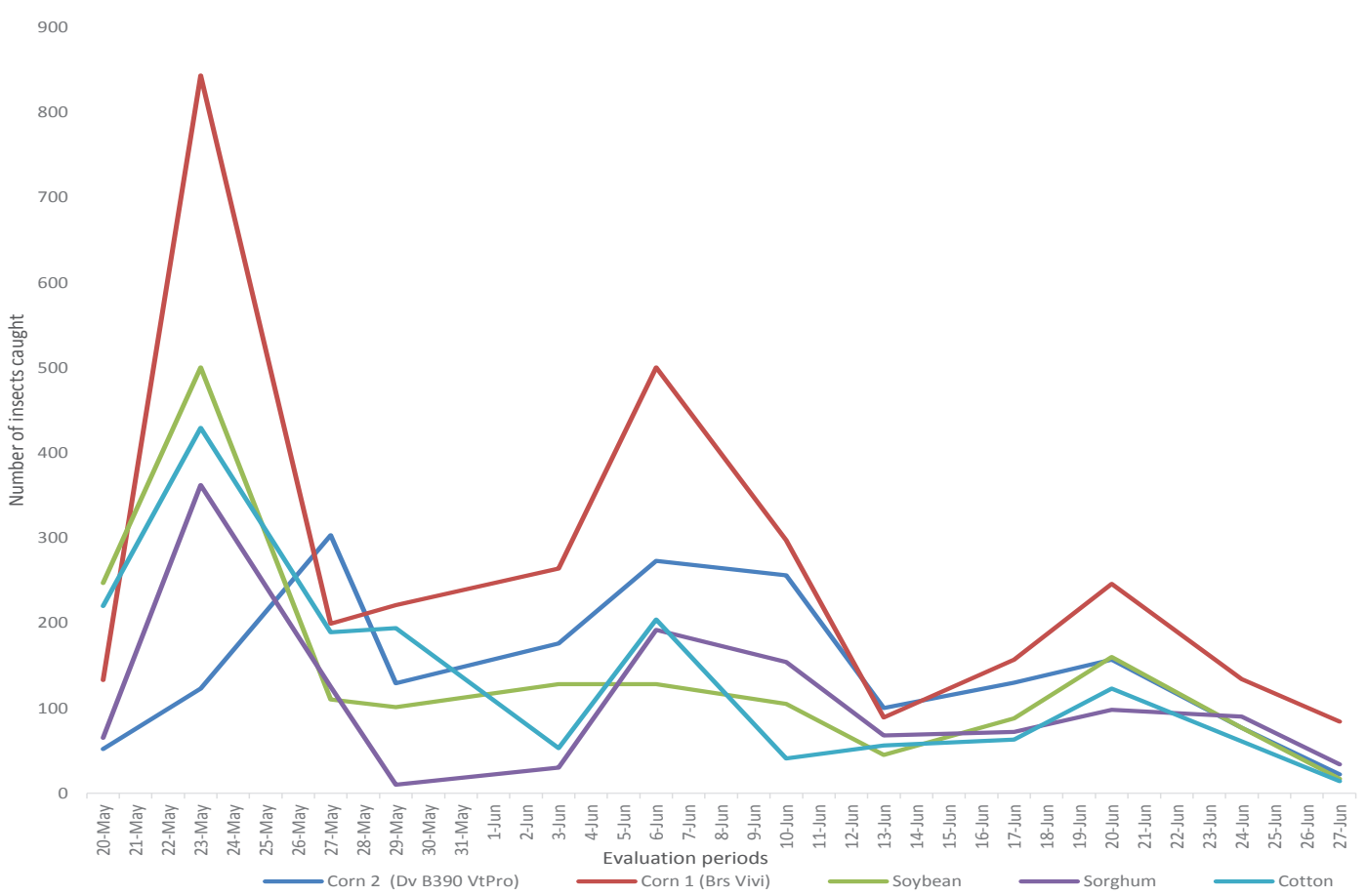

Figure 2. Euxesta mazorca population peaks during polyculture in the experiment fields of Embrapa in Sete Lagoas, MG.

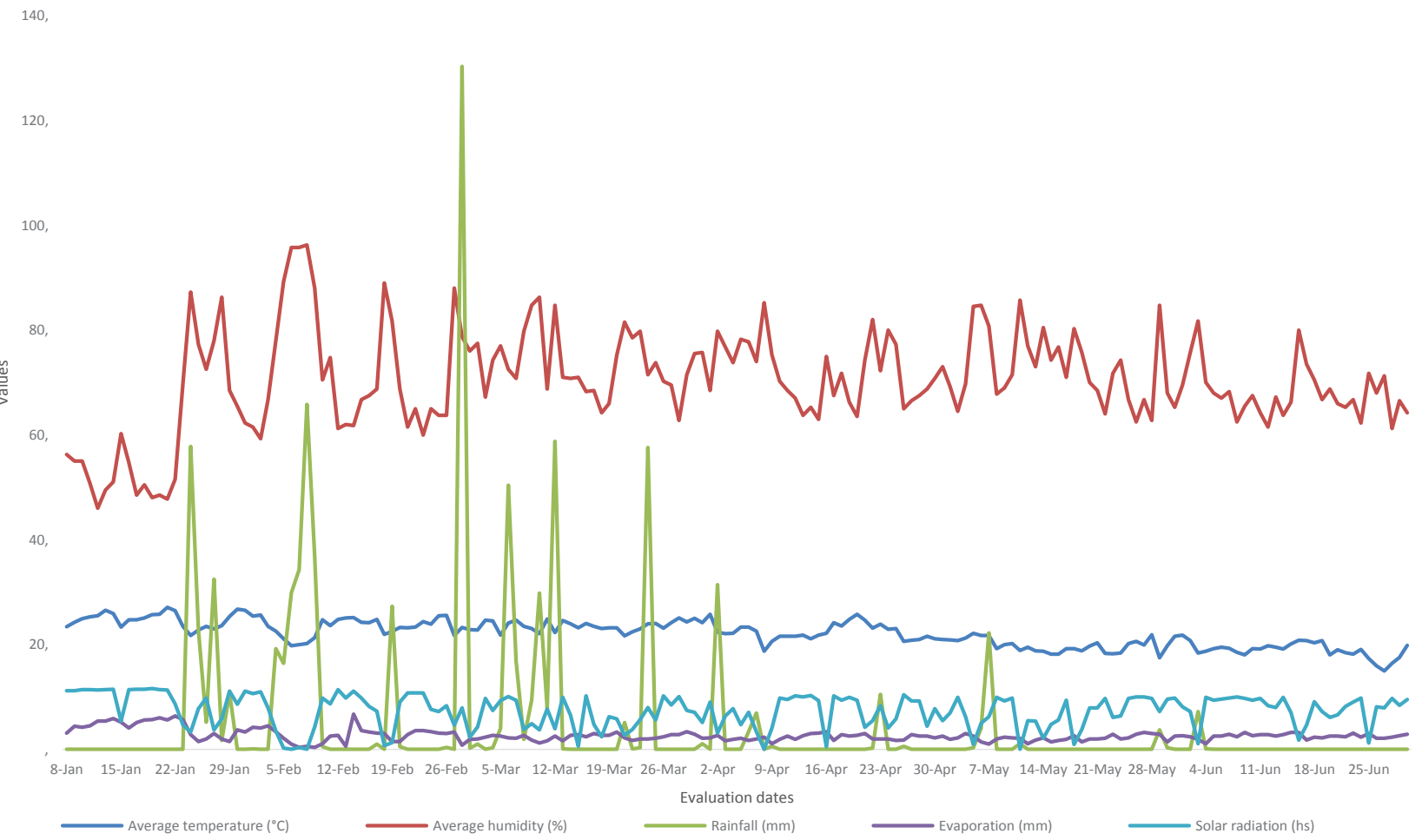

Figure 3. Meteorological data of the evaluation period of the polyculture in the fields of Embrapa in Sete Lagoas, $\mathrm{MG}$ 
providing microhabitats for refuge and/or survival as they provide pollen and nectar to the food supply for both, pests and natural enemies. However, the biological control of Euxesta spp. is still quite restricted (Kalsi et al., 2014).

Plant susceptibility is higher at the reproductive development stage, when more insects are attracted to the plant (Cruz et al., 2011b). Moreover, in both areas, the number of females collected in the traps was greater than the number of males. Both species collected in this experiment are also responsible for large losses in the MG vegetable belt, resulting in total loss of fresh sweet maize (Bertolaccini et al., 2010). In maize, insect is also opportunistic, taking advantage of the damage caused by Helicoverpa zea (Boddie, 1850) (Lepidoptera, Noctuidae) to facilitate oviposition. This fact could explain the large amount of Euxesta sp. during the pollination and filling period of maize grains (Cruz et al., 2011).

E. eluta and E. mazorca occurred in both areas, with maize and wheat. The number of individuals collected in the traps placed on corn was higher than the number of individuals collected in the wheat area (Table 2). In both cases, the maximum number of individuals was directly related to the phenological stage of the plant, and the capture peak occurred between August and September (Table 2).
In the second experiment (wheat), both species presented population peaks at different dates (Table 2 ). The number of E. eluta was higher on the tenth evaluation date, with an average of 97.75 individuals captured; a second population peak occurred on the sixteenth assessment day with 84.26 individuals captured. Euxesta mazorca also showed peak at the sixteenth assessment day, with an average of 23.38 trapped adults (Figure 2). The average number of E. eluta caught in the traps was much higher than the number of E. mazorca. The mean of $601.11 \mathrm{E}$. eluta adults represented $82 \%$ of the total, insects captured while the remaining $18 \%$ refer to the 129.35 individuals of E. mazorca (Table 2). E. eluta had significantly higher values of females, with a sex ratio of 1:7.5 adults (Figure 3 ). The number of males of E. mazorca caught in McPhail traps was 5.3 times lower than the number of females of the same species (Table 2). E. eluta sex ratio did not differ significantly in maize and wheat treatments $(0.51$ and 0.56 respectively), and the sex ratio of E. mazorca did not differ significantly from the crops (0.64 and 0.69 respectively); however, there was a significant difference between species (Table 2).

The most intense population peak occurred in the area cultivated with corn. On the 14th and 15th day of evaluation, the number of E. mazorca

Table 2. Number of adults caught and sex ratio of Euxesta eluta and Euxesta mazorca in maize and wheat in the experimental fields of Embrapa in Sete Lagoas, MG.

\begin{tabular}{cccc}
\hline & \multicolumn{2}{c}{ Average number of captured insects } & Sexual ratio \\
\hline Treatments/Crops & Euxesta eluta & Euxesta mazorca & Euxesta eluta \\
\hline Maize & $327.36 \mathrm{Aa}$ & $535.84 \mathrm{Aa}$ & $0.51 \mathrm{Aa}$ \\
\hline Wheat & $131.02 \mathrm{Aa}$ & $732.19 \mathrm{Ba}$ & $0.56 \mathrm{Aa}$ \\
\hline CV (\%) & & & 43.81 \\
\hline F & & 0.81 & 0.65 \\
\hline
\end{tabular}

Means followed by the same capital letter in the column do not differ from each other by Tukey's test at the 5\% probability level. 
collected in this area was significantly higher than the other samplings (Figure 4), and two days after a second population peak occurred for the same species in the same area. The E. eluta species presented three median population peaks during the evaluation dates, still in the area destined to corn cultivation (Figure 4). Both species showed small and constant peaks throughout the wheat area assessments. These results suggest that population peaks are associated to maize plant physiology (Figure 4). Meteorological data showed no influence on the number of insects collected in the traps in any of the species studied (Figure 5).

The presence of Euxesta spp. during the vegetative developmental stage of the plants suggests that it may be growing in some alternative host, including the most advanced maize plant. On the other hand, the significant increase in the pest population coincided with the most susceptible phase of the host plant, indicating that the plant in this phase is the most important factor to attract the insect. However, once the pest is within the target area, the additional food source, such as the protein used in this research, becomes an important point for the pest that provides supplemental feed, especially for the female (Cruz et al., 2011a).

In the case of wheat, sorghum, cotton and soybeans, although the Euxesta species has not yet been considered a pest, the presence of adults in the growing area may indicate the possibility of the insect surviving on this plant. This may be supported by the peak population coinciding with the stage of reproductive development of the plant, the preferred insect target (Cruz et al., 2011b).

The proximity to other crops can also explain the presence of this insect, since larvae and adults are commonly found feeding a variety of plants, such as fruits, plant roots and organic matter of crop remains (University of Florida, 2012). Maize, especially sweet maize, is the crop preferred by flies and the only one that suffers serious damage in Central America, South America, North America and the Caribbean (University of Florida, 2012; Bertolaccini et al., 2010; Seal \& Jannson, 1989).

According to Frías (1981), temperature and humidity are factors that directly interfere in the abundance of the populations of the representatives of the genus Euxesta. Surveys carried out in Chile showed differences between the development time, fecundity and fertility of two Euxesta species, E. eluta and Euxesta annonae (Fabricius). This could be the explanation for the population peak of the two species during the polyculture experiment at the beginning of the experimental evaluations during the month of March, which is a month of high rainfall in the savana region of Minas Gerais/Brazil. This population peak was higher than the second population peak by the time of grain filling of the two maize species in the area.

However, polyculture was efficient in reducing Euxesta. Compared with the first experiment, in which two crops (maize and wheat) were planted, being the maize the main crop of attack, the number of insects captured was approximately nine times the number of insects captured in the polyculture. The plant diversity found in polyculture shows a great influence on the stability of the population density of phytophagus insects, since it favors the biological and dynamic aspects of the populations of beneficial insects, cooperating for natural biological control the quantity and quality of the food available in that area, such as inflorescence nectar, pollen, presence of prey, alternative hosts and microhabitat variations. It, therefore, represents favorable conditions for the 


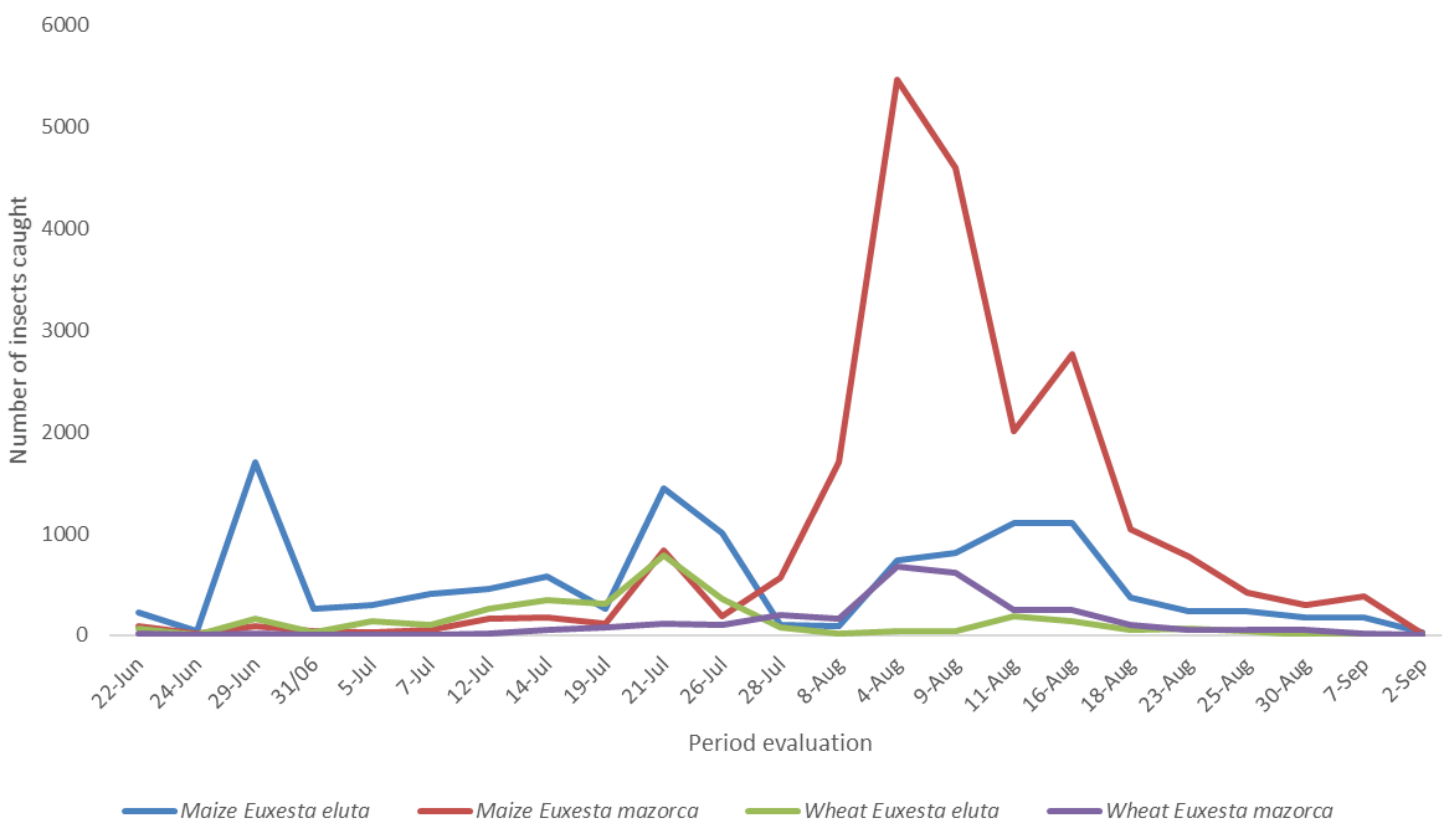

Figure 4. Population peaks of Euxesta mazorca and Euxesta eluta in the experimental area planted with maize in the experimental fields of Embrapa in Sete Lagoas, MG.
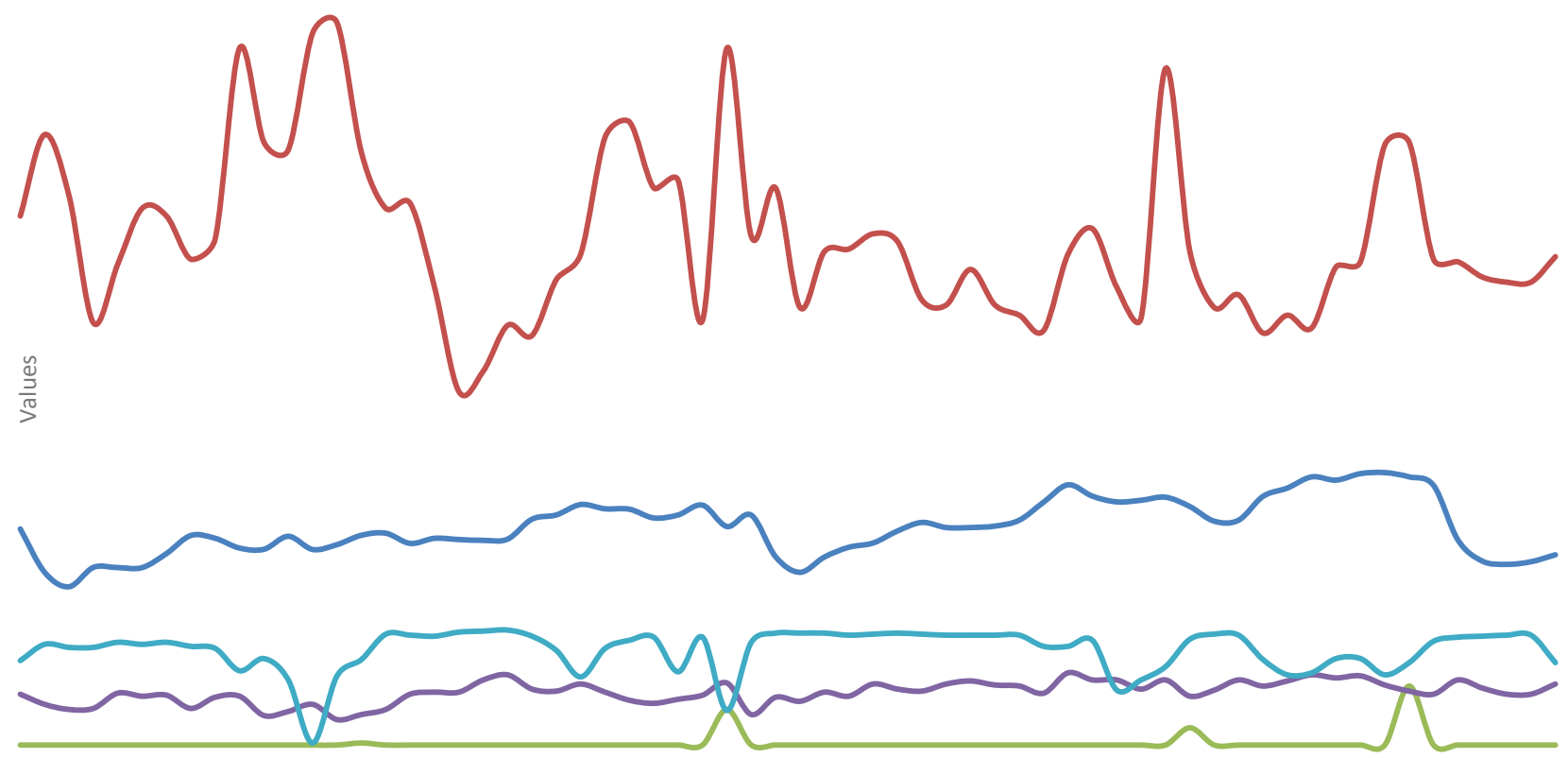

Evaluation dates

- Average temperature $\left({ }^{\circ} \mathrm{C}\right) \quad$ Average humidity $(\%) \quad$ Rainfall $(\mathrm{mm}) \quad$ Evaporation (mm) Solar radiation (hs)

Figure 5. Average temperature, relative humidity, rainfall, evaporation and solar radiation from the beginning to the end of the implementation of the experiment in the area cultivated with maize and wheat in Embrapa in Sete Lagoas, MG. 
development and maintenance of natural enemies in these agro ecosystems. In addition, polyculture disfavored the encounter and subsequent attack of the host plant by herbivorous insects (Altieri et al., 2003).

Considering the detection of E. eluta and $E$. mazorca species in the area of maize (preferred host), wheat (where both species are not yet recognized as pests), and polyculture, it is concluded that the use of associated attractive food source to the McPhail trap is a pest detection tool on the presence of the insect in other hosts.

Recalling that the monitoring and management tactics are poorly developed, being carried out before the filling of grains. Adults can be detected late in the afternoon, when they land on plants and copulate in the ears (University of Florida, 2012). It is also concluded that the most important factor to attract the pest to the plant is the reproductive phase, attracting for oviposition and the development of larvae.

\section{References}

ALTIERI, M. A.; SILVA, E. N.; NICHOLLS, C. I. O papel da biodiversidade no manejo de pragas. Ribeirão Preto: Holos, 2003. 226 p.

BERTOLACCINI, I.; BOUZO, C.; LARSA, M.; FAVARO, J. C. Especies del género Euxesta (Díptera: Ulidiidae: Ottitidae) plagas de maíces dulces $\mathrm{Bt}$ en la provincia se Santa Fé, Argentina. Revista da Sociedade Entomologia Argentina, v. 69, n. 1, p. 123-126, 2010.

BJARNASON, M.; VASAL, S. K. Breeding of quality of protein maize (QPM). In: JANICK, J. (Ed.). Plant breeding reviews. New York: John Wiley \& Sons, 1992. v. 9, p. 181-216. DOI: 10.1002/9780470650363.ch7.

BRANCO, M. C.; VILLAS BOAS, G. L.; REIFSCHNEIDER, F. J. B.; CRUZ, I. Avaliação da resistência a Helicoverpa zea (Boddie) (Lepidoptera:
Noctuidae) e Euxesta sp. (Diptera: Otitidae) em linhagens de milho doce. Anais da Sociedade Entomológica do Brasil, v. 23, n. 1, p. 137-140, 1994.

CAPINEIRA, J. L. Handbook of vegetables pests. San Diego: Academic Press, 2000. 729 p.

CRUZ,I.(Ed.).ManualdeIdentificaçãodepragas domilho e de seus principais agentes de controle biológico. Brasília, DF, Embrapa Informação Tecnológica, 2008. v. 1, 192 p.

CRUZ, I.; FIGUEIREDO, M. L. C.; SILVA, R. B. Controle biológico de pragas de milho. Ciência \& Ambiente, v. 43, p. 165-190, 2011a.

CRUZ, I.; SILVA, R. B.; FIGUEIREDO, M. L. C.; DIAS, A. M. P.; SARTO, M. C. L. D.; NUESSLY, G. S. Survey of ear flies (Diptera, Ulidiidae) in maize (Zea mays L.) and a new recordo of Euxesta mazorca Steyskal in Brazil. Revista Brasileira de Entomologia, v. 55, n. 1, p. 102108, 2011b. DOI: 10.1590/S0085-56262011000100016.

FERREIRA, D. F. Sisvar: a computer statistical analysis system. Ciência e Agrotecnologia, v. 35, n. 6, p. 10391042, 2011. DOI: 10.1590/S1413-70542011000600001.

FRÍAS, D. L. Diferencias de microhabitats entre Euxesta eluta y Euxesta annonae (Diptera:Otitidae). Agricultura Técnica, v. 41, p. 89-94, 1981.

GALLO, D.; NAKANO, O.; SILVEIRA NETO, S.; CARVALHO, R. P. L.; BAPTISTA, G. C. de; BERTI FILHO, E.; PARRA, J. R. P.; ZUCCHI, R. A.; ALVES, S. B.; VENDRAMIM, J. D.; MARCHINI, L. C.; LOPES, J. R. S.; OMOTO, C. Entomologia agrícola. Piracicaba: FEALQ, 2002. 920 p. (Biblioteca de Ciências Agrárias Luiz de Queiroz, 10).

GOULD, F.; BLAIR, N.; REID, M.; RENNIE, T. L.; LOPEZ, J.; MICINSKI, S. Bacillus thuringiensis-toxin resistance management: stable isotope assessment of alternate host use by Helicoverpa zea. Proceedings of the National Academy of Science of the United States of America, v. 99, n. 26, p. 16581-16586, 2002.

DOI: $10.1073 /$ pnas.242382499. 
GOYAL, G. Morphology, biology, and distribution of maize-infesting Ulidiidae. 2010. Thesis (Master) - University of Florida, Gainesville, 2010.

GUimarÃes, P. E. de O.; PARENTONI, S. N.; PACHECO, C. A. P.; PAES, M. C. D.; VASCONCELOS, M. J. V.; MONTEIRO, M. A. R.; MAGNAVACA, R.; LOPES, M. A.; SANTOS, M. X. dos; GAMA, E. E. G. e; MEIRELLES, W. F. BR 451: milho de alta qualidade protéica. Sete Lagoas: Embrapa Milho e Sorgo, 2004. 4 p. (Embrapa Milho e Sorgo. Comunicado Técnico, 111).

HUEPE, S. G.; VARGAS; H. C.; FRÍAS, D. L.; BOBADILLA, D. G. Estudio morfológico y ecológico de Euxesta eluta Loew y Euxesta mazorca Steyskal (Diptera: Otitidae) en cultivares de maíz en El Valle de Lluta, Arica. Revista Chilena de Entomologia, v. 14, p. 17-24, 1986.

KALSI, M.; SEAL, D. R.; NUESSLY, G. S.; CAPINERA, J. L.; MARTIN, C. G. Seasonal timing, abundance, and predatory status of arthropods associated with maize infested by picture-winged flies (Diptera: Ulidiidae) in south Florida. Florida Entomologist, v. 97, n. 1, p. 168178, 2014. DOI: 10.1653/024.097.0123.

LINK, D.; STOCK, L.; CERVI, J. A.; PADOIN, J.; GIULIANI, D. Ocorrência da mosca Euxesta sp. em milho-doce na região de Santa Maria. Revista do Centro de Ciências Rurais, v. 14, n. 2, p. 93-99, 1984.

MIRANDA, J. E.; SUASSUNA, N. D.; MORELLO, C. de L.; SILVA, M. V. de F.; FREIRE, E. C. Doença azul do algodoeiro: novos aspectos a serem considerados no manejo. Campina Grande: Embrapa Algodão, 2008. 11 p. (Embrapa Algodão. Circular Técnica, 121).

NUESSLY, G. S.; CAPINERA, J. L. Corn silk fly. Gainesville: University of Florida, 2006. 5 p.

NUESSLY, G. S.; CAPINERA, J. L. Cornsilk fly (suggested common name), Euxesta stigmatias loew
(Insecta: Diptera: Otitidae). Gainesville: University of Florida, 2010.

PEDROTTI, A.; PAUletTO, E. A.; GOMES, A. S.; TURATTI, A. L.; CRESTANA, S. Sistemas de cultivo de arroz irrigado e a compactação de um Planossolo. Pesquisa Agropecuária Brasileira, v. 36, n. 4, p. 709-715, 2003. DOI: 10.1590/S0100-204X2001000400015.

SEAL, D. R.; JANNSON, R. K. Biology and management of maize-silk fly, Euxesta stigmatis Loew (Diptera: Ottitidae) on sweet maize in southern Florida. Proceedings of the Florida State Horticultural Society, v. 102, p. 370373, 1989.

STEYSKAL, G. C. Família Otitidae. In: VANZOLINI, P. E.; PAPAVERO, N. (Ed.). Um catálogo de Diptera das Américas ao Sul dos Estados Unidos. São Paulo: Secretaria da Agricultura, 1968. p. 1-31.

STEYSKAL, G. C. Otitidae Familia. In: PEDRA, I. A.; SABROSKY, C. W.; WIRTH, W. W.; FOOTE, R. H.; COULSON, J. R. (Ed.). Um catalogo de Diptera da América do Norte contra o México. Washington: United States Department of Agriculture, 1965. v. 276, p. 642-654. UNIVERSITYOFFLORIDA.MaizesilkflyEuxestastigmatias Loew (Insecta: Diptera: Otitidae). Gainesville, 2012.

VASAL, S. K.; VILLEGAS E.; BJARNASON, M.; GELAW, B.; GOERTZ, P. Genetic modifiers and breeding strattegies in developing hard endorperm opaque-2 materials. In: POLLMER, W. G.; PHILLIPS, R. H. (Ed.). Improvement of quality traits of mayze for grain and silage use. London: Matinus Nijhhoff, 1980. p. 37-73.

VILLAS BÔAS, G. L.; FRANÇA, F. H. Controle da lagarta da espiga Heliothis zea (Bod., 1850) (Lepdoptera: Noctuidae) e da mosca Euxesta sp. (Diptera: Otitidae) em milho doce. In: CONGRESSO BRASILEIRO DE ENTOMOLOGIA, 12. ENCONTRO SOBRE MOSCA DAS FRUTAS, 2., 1989, Belo Horizonte. Resumos. Belo Horizonte: Sociedade Entomológica do Brasil, 1989. p. 290. 